\title{
Reformation Protection on Indonesian Worker Regim To Asean Community 2025
}

\author{
${ }^{1}$ Lanny Ramli \\ Faculty of Law, Airlangga University \\ Surabaya, Indonesia \\ lannyramli@yahoo.com
}

\author{
${ }^{2}$ Koesrianti \\ Faculty of Law, Airlangga University \\ Surabaya, Indonesia \\ koesrianti@gmail.com
}

Abstract- Until now Indonesian worker not fully protection faced ASEAN Economic Community (AEC) free trade liberalism in ASEAN COMMUNITY especially undocumented Indonesian worker. Actually, there is regulation Act Number 39 Year 2004 for protection Indonesian worker but we should finding the new model for more protection to all Indonesian worker in ASEAN country. The state by the government has responsibility to achieve it.

The responsibility of government start from several concepts. Sociale Rechtsstaat concept was started due to economic crisis after world war II that created "welvaartsstaat" concept and later known as "verzorgingsstaat". Welvaartsstaat and verzorgingsstaat are concepts about sociology and politics. The concept of "werzorgingsstaat" is considered too expensive to be applied, so Loebers Cabinet conducted another concept called "warborgstaat". Through this concept, government provided minimum "warborg" and its weakness relies on the society to legalize it using private insurance. In juridical concept, A.M Donner stated that the term of "sociale rechtsstaat" is better than "welvaartsstaat".

Through the changes mentioned above, main factors of "sociale rechtsstaat" are: elementair recht, economische mogelijkheden, sociale spreiding.They are connected to the law protection for people towards the government action, in sociale rechtsstaat, the law protection principle is used for the protection of social rights, economy rights, and cultural rights.

Connecting to the rights character (in rechtsstaat that is liberal and democratic), "the rights to do" in sociale rechtsstaat creates "the rights to receive". Connecting to the law protection means, the more complex law protection system for people, the more means needed in order realize people rights protection, particularly social rights, economy rights, and cultural rights.

In "verzorgingsstaat" concept ("sociale rechtsstaat" juridicial concept) by P. Schnabel, it is said that country is responsible for protecting not only civil freedom, but also people life style (levenstjil). In other words, "verzorgingsstaat" is the development of the country function as "nachtwaker staat" During the development of "verzorgingsstaat", the country influence towards the individuals transform into three ways:

First: direct effect as the result of acknowledgement and protection towards the social rights.

Second: indirect effect as the result of government staff formation which is completed with power and skill.

Third: hopes for solving public problems by the help of the superiors

To reform the protection model for Indonesian worker Prag argues that public law applicable to the actions of government as rulers, while private law is the law that applies to other legal relations. Romijn states that the laws of government applicable for the relationship between governments and governed when performing their governance duties.

How we find the social justice and non discriminative model and the structure of regulation for protection Indonesian worker especially for undocumented worker as best practice because Act Number 6 Year 2012 as Ratification of International Covenant of Right Protection for Migran Worker and Their Family ( 1990 ) not enough protected Indonesian worker in other country. Actually to find the social justice and 
non discriminative model and the structure of regulation for protection Indonesian worker especially for undocumented worker as best practice we must look at the blue print of ASEAN Economic Community (AEC).

\section{State of problem}

How to reform Indonesian worker's regim protection to support ASEAN COMMUNITY 2025 ?

\section{Keywords-ASEAN COMMUNITY; Migrant Worker; Sociale Rechtstaat; Reform Regim.}

\section{INTRODUCTION}

Sociale Rechtsstaat concept is arise form of liberale democratische rechtsstaat with some changes, namely.[1] The formal component of the idea of rechtsstaat obtains a material component (so that it is both formal and material). Formal components relate to the rights of classical freedom and the material component of giving social rights, these rights which demand the active action of the government, which then have a particular effect on the administrative law.[2]

Freedom and equality (vrijheid en gelijkheid) originally in the concept of liberale democratische rechtsstaat is of a formal juridical nature, in the concept of sociale rechtsstaat interpreted in real life in society (reele maatschappelijke gelijkheid), that there is no absolute equality in society between individual one other. The right to social, economic and cultural rights is of primary concern. As an example in the new Grondwet Netherland (1983) in addition to classical rights, social rights are specifically regulated such as housing issues linked to a healthy living environment (art.21) people's health problems (art.22.1).[3]

The comparison of "liberaal-democratische rechtsstaat" and "sociale rechtsstaat" is as follows:[4]

1) In liberaal democratische rechtsstaat the concept of freedom and equality is only formal juridical, while in sociale rechtsstaat freedom and real equality in society.

2) In liberaal democratische rechtsstaat the rights of human rights concerning classical rights, while in sociale rechtsstaat of human rights rights regarding classical rights and social rights.
3) In liberaal democratische the preferred rechtsstaat is the legitimacy of political power while in sociale rechtsstaat which put forward is the economic power and its relation to political power.

4) In liberaal democratische rechtsstaat, wet is defined as the ratio of scripta whereas in sociale rechtsstaat, wet is a legal tool for realizing wisdom (beleid).

5) In liberaal democratische rechtsstaat, public interest is defined as the interests of the state or the interests of the bourgeoisie while in sociale rechtsstaat public interest is defined as the interests of all people (democratic)

Human rights related to social rights recognized in sociale rechtsstaat include industrial relations. Industrial relations is a system of relationships formed between actors in the process of production of goods and / services consisting of elements of employers, workers / laborers and government based on the values of Pancasila and the Constitution of the Republic of Indonesia Year 1945. From the definition of industrial relations which shows the existence of three parties namely workers, employers and government, indicating the existence of government elements as an interventionist in the relations of workers and employers. The State (in this case represented by the Government) is the agency (tool) of the community that has the power to regulate human relationships within the community. Power has its limits. From the literature is known a variety of ways and means that can be used to supervise and limit power. Overall it can be summarized in three aspects:

(a) morality or religion

(b) ethics

(c) the law.[5]

Of the three aspects, the law is the aspect that is considered the most concrete and effectively supervise and limit the power of state organizers. It is only through law that it is possible to apply (the imposition of sanctions in concrete terms, ie to the rulers (government) whose actions result in harm to society. Required law requires the existence of a certain power not to live only as a series of rules or mere moral principles.Instead, requires most laws for two conditions. 
First, is to provide legitimacy to its implementation in public life. Based on legal principles, power transforms into an authority or authority that is considered and legitimately recognized by the people it controls.[6]

Secondly, that law is needed so that power grows and develops into arbitrariness (despotism). In the second case it appears that the role is very important, as well as the problem, from the existence of law as the supervisor and limiting the power of the rulers.

From the point of etymology, power is defined as "the ability to act or act." (Power is an ability to do or act). While in the dictionary of law, power is given as:

"..., an ability on the part of a person to produce a change in a given legal; relation by doing a given act. "[7]

Or also:

"..., is a liberty or authority reserved by, or limited to, a person to dispose of or personal property, for his own benefit, or benefit of others, or enabling one person to dispose of interest which is vested in another." :

Understanding according to the dictionary language and the dictionary of the law shows that power is an ability that is in the relationship between humans. The importance of the relationship between human (social) as a place of application of power, proposed by Miriam Budiardjo:

"... the ability of a person or a group of human beings to influence the behavior of a person or other group in such a way that the past behavior is in accordance with the wishes and purposes of the person who has that power.":

\section{Ossip K.Flechteim poses the following powers}

"... is the whole of the abilities, relationships and processes that result in the obedience of others ..., for the purposes set by the holder of power.":

From some understanding that has been presented, can know some essential things about power that is:

a. is the ability to influence or control other parties;

b. contained within a social interaction;
From all of explanation to faced the problem may be 'ill-treatment' of ill-treatment by immigration authorities or by authorities, abusive and exploitative working conditions, lack of basic rights protection at work, limited access to 'social security', discrimination systematized, and 'xenophobia and prejudice' factors. Illegal labor migrants, also called irregular migrants, are typically experienced by undocumented Indonesian workers, living and working in weak safety and very limited protection (the very margins of basic protections and safety). In some cases are usually experienced by migrant workers trafficking cross country, their working conditions can be equated with forced labor. From the description of the situation of migrant workers like this, the improvement and protection of the rights of migrant workers is a priority of the countries, including Indonesia, mainly because there are so many illegal labor migrants, undocumented Indonesian workers are abroad without adequate protection from the state.

Indonesian workers working abroad are the right of every Indonesian citizen. This is guaranteed by the 1945 Constitution of the 1945 Constitution which states that "every citizen shall have the right to work and a livelihood worthy of humanity". This is further stipulated in article 8 of Law 39/2004 which states that: "every prospective TKI / Laborer has the same right and opportunity to work outside the country. Therefore, the government must facilitate, provide services, organize and supervise and oversee the process of placement of workers abroad. The principles in placement of TKI in the framework of the protection of TKI as regulated in Law 39/2004 are as follows:

1. Placement of labor migrants may only be made to a country that has laws and regulations protecting foreign workers / migrant workers (article 27);

2. Placement of migrant workers may only be conducted to the destination country whose government has entered into an agreement with the Indonesian government (MOU);

3. It is prohibited to place migrant workers on work that is contrary to human values, norms of morality and legislation (art. 30); 
4. The destination country of the placement is not in a state of war, natural disaster, contracted outbreak (article 73);

5. Placement of overseas workers should pay attention to the importance of the availability of labor in accordance with domestic needs (art. 81).

The state is responsible and the responsibility of ASEAN as a regional organization in the region to establish or develop legal instruments for the protection and improvement of the rights of migrant workers through an agreement of a legally binding nature. The declaration of Cebu 2007 is only a guidance for ASEAN member countries. The declaration of Cebu has been revised or changed to adapt to the current conditions of ASEAN member countries, especially when ASEAN has agreed on the establishment of ASEAN Community in 2015 consisting of three communities, namely ASEAN Political Security Community (APSC), ASEAN Economic Community (AEC) and ASEAN SocioCultural Community (ASCC). In the 2016 Kuala Lumpur Declaration when ASEAN formally declared the formation of ASEAN Community 2015, ASEAN agreed to establish an ASEAN socio-cultural society in 2025, a society that is engages and beneficial to the general public, and is inclusive, sustainable, durable and dynamic .[9] It is also agreed that ASEAN countries will implement and realize an inclusive ASEAN society that enhances the quality of life, rights, women, youth, the eldery / older persons, persons with disabilities, migrant workers, and vulnerable and marginalised groups. "[10]

The authority of the state to accept a person to be a citizen, to renounce citizenship, even to expel it will be faced with the choice of individuals to enter, stay and leave the country. Free flow of people almost matches its intensity with the free flow of goods. Therefore, Indonesia should protect migrant workers regardless of their status. The labor migrants should be well managed, that prospective TKIs are really qualified who can be sent to work abroad. So in the future, migrant workers can compete with migrant workers from other countries, for example from the Philippines, Bangladesh, Sri Lanka, and other countries. The weakness of migrant workers lies in the ability to speak English. Compared with migrant workers from the Philippines, Indonesian migrant workers are inadequate, so the salaries of migrant workers are lower than migrant workers from the Philippines, for the same job. With a large population, and selected quality, this will increase the economic growth of Indonesia.

Make bilateral agreement with destination country of TKI. Indonesia has entered into bilateral and multilateral agreements with several destination countries. Bilateral agreements containing protection have been done and amounted to 32 pieces with other countries, in the form of intergovernmental agreement, MoU, Joint Declaration, Letter of Intent, and others where some countries are concentrated from TKI namely Malaysia, South Korea, Saudi Arabia, Jordan, Japan , and Qatar. Problems of migrant workers not only occur in the destination country, because the root of the problem already exists when prospective labor migrants undergo a process of kemangakatan in the country. From the departure process which consists of pre-placement, placement and post-placement then the most problematic is in the pre-placement phase, because prospective migrant workers are not prepared seriously and earnestly, so that the candidates who are sent are not qualified and eventually many problems which arise when the TKI is in the country of placement.

In addition, the form of protection may be an MOU with the destination country. The Philippines has best practice practices for the protection of their migrant workers, especially domestic workers, in which the Philippines has special agreements on the protection of domestic workers' rights as outlined in the MOU between the Philippines and Saudi Arabia, as set forth in table 2 below. The MoU contains agreements from two countries on all matters relating to $\mathrm{TKI}$, containing general matters. MoU conducted by the Philippines which is only related to migrant domestic worker workers is best practices, since this type of work does not get protection in the labor law in the country of placement.

\section{Recommendation}

To make reformation regim to protect our Indonesia worker there are several ways:

It is necessary for the cooperation of sending and receiving countries as countries have shared responsibility for the fate of migrant workers, which has contributed to the growth of the national economy in both sending and receiving countries, either directly or indirectly directly. 
1. It should be considered that there is a zero fee and cost policy for the recruitment costs of migrant worker placement. So there is a just and humane recruitment. This once again requires the cooperation of the sending country and the receiving country.

2. Innovative innovations such as e-recruitment are required, thus avoiding the placement of middle man or brokers, as well as facilitating and easing prospective migrant workers.

3. It needs a campaign about enlightenment and dissemination of overseas employment information that is easily accessible, for example through the internet or hand phone applications .. So it can provide opportunities and motivation to the community to conduct legal migration.

4. It is necessary to establish a body that focuses on TKI related to their welfare and families of migrant workers. This institution can reward migrant workers for their services and dedication, for example as the best migrant workers. Can also give awards to families of migrant workers, for example by providing scholarships to children of migrant workers based on certain conditions.

\section{REFERENCES}

[1] Philipus M.Hadjon,Perlindungan Hukum Bagi Rakyat, Peradaban, Jakarta, 2007, p.72-73

[2] De Haan, Bestuursrecht in de Sociale Rechtstaat,ontwikkeling organisatie organisatie instrumentarium, Kluwer, Deventer, 1996,p.17.

[3] Philipus M.Hadjon.,Loc.Cit

[4] Ibid, p.75

[5] Sjachran Basah,Perlindungan Terhadap Sikap Tindak Administrasi Negara, Alumni,Bandung,1996,p.3

[6] Mc Iver, terjemahan Laila Hasyim ,Jaring Jaring Pemerintahan, Aksara Baru, Jakarta, 1995, p.98

[7] Henry Campbell Black, Black's Law Dictionary, West Publishing, St.Paul Minessota,1988,p.609.
[8] Miriam Budiardjo, Op.Cit., p.35.

[9] Dany Jumadil Akhir, Dampak Negatif Moratorium TKI Rugikan Indonesia, Okezone online, 11 Juni 2015, lihat http://economy.okezone.com/read/2015/06/11/ 320/1163789/dampak-negatif-moratorium-tkirugikan-indonesia (dikunjungi 16/03/2017)

[10] ASEAN 2025: Forging Ahead Together, ASEAN Sekretariat, Jakarta, p.16 